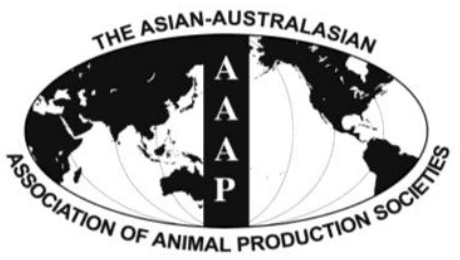

Asian Australas. J. Anim. Sci.

Vol. 26, No. 9 : 1304-1312 September 2013

http://dx.doi.org/10.5713/ajas.2013.13175

www.ajas.info

pISSN 1011-2367 elSSN 1976-5517

\title{
Effects of Ensiling Fermentation and Aerobic Deterioration on the Bacterial Community in Italian Ryegrass, Guinea Grass, and Whole-crop Maize Silages Stored at High Moisture Content
}

\author{
Yanbing $\mathrm{Li}^{*}$ and Naoki Nishino ${ }^{1}$ \\ College of Animal Science and Veterinary Medicine, Heilongjiang Bayi Agricultural University, \\ Daqing, Heilongjiang 163319, China
}

\begin{abstract}
The effects of storage period and aerobic deterioration on the bacterial community were examined in Italian ryegrass (IR), guinea grass (GG), and whole-crop maize (WM) silages. Direct-cut forages were stored in a laboratory silo for 3, 7, 14, 28, 56, and $120 \mathrm{~d}$ without any additives; live counts, content of fermentation products, and characteristics of the bacterial community were determined. 2,3-Butanediol, acetic acid, and lactic acid were the dominant fermentation products in the IR, GG, and WM silages, respectively. The acetic acid content increased as a result of prolonged ensiling, regardless of the type of silage crop, and the changes were distinctively visible from the beginning of GG ensiling. Pantoea agglomerans, Rahnella aquatilis, and Enterobacter sp. were the major bacteria in the IR silage, indicating that alcoholic fermentation may be due to the activity of enterobacteria. Staphylococcus sciuri and Bacillus pumilus were detected when IR silage was spoiled, whereas between aerobically stable and unstable silages, no differences were seen in the bacterial community at silo opening. Lactococcus lactis was a representative bacterium, although acetic acid was the major fermentation product in the GG silage. Lactobacillus plantarum, Lactobacillus brevis, and Morganella morganii were suggested to be associated with the increase in acetic acid due to prolonged storage. Enterobacter cloacae appeared when the GG silage was spoiled. In the WM silage, no distinctive changes due to prolonged ensiling were seen in the bacterial community. Throughout the ensiling, Weissella paramesenteroides, Weissella confusa, and Klebsiella pneumoniae were present in addition to L. plantarum, L. brevis, and L. lactis. Upon deterioration, Acetobacter pasteurianus, Klebsiella variicola, Enterobacter hormaechei, and Bacillus gibsonii were detected. These results demonstrate the diverse bacterial community that evolves during ensiling and aerobic spoilage of IR, GG, and WM silages. (Key Words: Bacteria, Denaturing Gradient Gel Electrophoresis, Italian Ryegrass, Guinea Grass, Whole-crop Maize, Silage)
\end{abstract}

\section{INTRODUCTION}

Fermentation of silage depends on the competition between different groups of microorganisms. Desirable microorganisms are lactic acid bacteria (LAB), which usually dominate over the ensilage process, whereas a number of undesirable microorganisms could also grow and bring about anaerobic or aerobic spoilage. Enterococci, lactococci, and pediococci are generally thought to initiate silage fermentation, whereas in the late stages more acidtolerant lactobacilli such as Lactobacillus plantarum and

\footnotetext{
* Corresponding Author: Yanbing Li. Tel: +86-459-6819002, Fax: +86-459-6819015, E-mail: yanbing_894@ hotmail.com

1 Department of Animal Science, Graduate School of Environmental and Life Science, Okayama University, Okayama 700-8530, Japan.

Submitted Mar. 27, 2013; Accepted Apr. 29, 2013; Revised May 17, 2013
}

Lactobacillus brevis may replace them (McDonald et al., 1991; Lin et al., 1992).

The degrees of successful fermentation can be approximately evaluated by determining the composition of the fermentation products. If the silage has a high proportion of lactic acid, the proliferation of non-LAB bacteria may be effectively inhibited, reducing dry matter (DM) loss and protein degradation during storage (McDonald et al., 1991). Information on associated microorganisms can help understand how the ensilage process can be optimized for improving productivity because various microorganisms in addition to LAB can produce the major fermentation products (e.g. lactic acid, acetic acid, and ethanol).

In the analysis of the silage microbial community, culture-independent procedures are increasingly being used. Traditional culture-based assays may be biased by the 
growth characteristics of the microbes and can detect culturable cells only (Giraffa and Neviani, 2001). According to the estimates obtained from microbial ecology studies, only $<10 \%$ of the microbial diversity present is culturable; hence, the use of selective media may lead to a non-representative assessment of the composition of the microbial community (Ampe et al., 1999). By using denaturing gradient gel electrophoresis (DGGE) analysis, we examined the microorganisms associated with fermentation and aerobic deterioration. The results of this analysis showed how conventional and non-conventional LAB species are involved in fermentation and aerobic stability (Li and Nishino, 2011a, 2011b) and how diverse bacteria are distributed in lateral and perpendicular directions within a bunker silo (Li and Nishino, 2011c).

Because high-moisture ensiling is best avoided in order to achieve acceptable fermentation, medium-moisture ensiling was examined in our previous studies ( $\mathrm{Li}$ and Nishino, 2011a; 2011b). However, in large-scale ensiling, high-moisture crops can be used to perform time-saving operations. Furthermore, temperate grass, tropical grass, and whole-crop cereal silages should be analysed to understand how silage bacterial communities differ among different crop species, accounting for the differences in the interpretations of the fermentation patterns. Dairy production is expanding from temperate to tropical countries; hence, procedures for ensiling need to be optimized to account for the increase in animal production in hot environments (Nussio, 2005).

The objectives of this study were to identify the bacteria associated with anaerobic storage and aerobic spoilage of Italian ryegrass (IR), guinea grass (GG), and whole-crop maize (WM) silages. Changes in the fermentation and the bacterial community were examined from the early stages of ensiling in order to understand how microorganisms compete with one another in the process of establishing a stable community.

\section{MATERIALS AND METHODS}

\section{Ensiling}

First growth of IR and GG were harvested at the late heading stage on 19th May 2009 and 4th August 2009, respectively, and chopped using a forage cutter to approximate lengths of $25 \mathrm{~mm}$. WM was harvested at the stage of half milk-line on 31st August 2009, and a precision-chop harvester was used to chop the crop to approximate lengths of $12 \mathrm{~mm}$. The chopped crop (300 g) was packed in a laminated plastic pouch (Hiryu BN12, Asahi Kasei Pax, Tokyo, Japan) and then tightly packed using a vacuum sealer (SQ-303, Asahi Kasei Pax, Tokyo, Japan). The size, thickness, and oxygen permeability of the pouch were $270 \times 400 \mathrm{~mm}, 0.075 \mathrm{~mm}$, and $44 \mathrm{~mL} \mathrm{~m}^{-2} \mathrm{~atm}^{-1}$ per day, respectively. The silages were made in triplicate and stored at ambient temperatures for 3, 7, 14, 28, 56, and $120 \mathrm{~d}$. No bacterial inoculant was made.

\section{Aerobic spoilage test}

After the silage was completely opened on d 14, 28, 56, and 120, half the content $(150 \mathrm{~g})$ was put into a polyethylene bottle $(500 \mathrm{~mL})$ without compaction. The top of the bottles was kept uncovered and exposed to air for $7 \mathrm{~d}$ in a room maintained at $25^{\circ} \mathrm{C}$.

\section{Chemical analyses and microbial enumeration}

Silage samples were obtained at the time of opening the silo and after conducting the aerobic stability test. DM contents were determined by drying the material in an oven at $60^{\circ} \mathrm{C}$ for $48 \mathrm{~h}$. The silage $\mathrm{pH}$ and lactic acid, short-chain fatty acid, and alcohol contents were determined from water extracts as described previously (Li and Nishino, 2011a). Water-soluble carbohydrates (WSC) were extracted with $800 \mathrm{~g} / \mathrm{L}(\mathrm{v} / \mathrm{v})$ ethanol, and the contents were determined by the phenol-sulphuric acid method (Parvin et al., 2010).

LAB counts were determined using de Man, Rogosa, and Sharpe agar and enterobacteria counts were obtained using violet red bile agar. Yeasts and moulds were enumerated on spread plates of yeast extract and malt extract agar ( $\mathrm{pH} 3.5$, obtained using sterilised lactic acid).

\section{Denaturing gradient gel electrophoresis}

Because preliminary experiments demonstrated that triplicate silages exhibited almost the same DGGE profiles, the DGGE was performed on 1 silage sample from 3 replications obtained at both the initial silo opening stage and after the aerobic stability test.

DGGE was performed as previously described (Li and Nishino, 2011a). In brief, the polymerase chain reaction (PCR) was used to amplify a variable (V3) region of the bacterial $16 \mathrm{~S}$ rRNA gene by using the forward primer GC357f (5'-CGCCCGCCGCGCGCGGCGGGCGGGG CGGGGGCACGGGGGGCCTACGGGAGGCAGCAG-3') and the reverse primer 517r $\left(5^{\prime}\right.$-ATTACCGCGGCTG CTGG-3'). The GC-clamp PCR products were separated according to their sequences with a DCode Universal Mutation Detection System (Bio-Rad Laboratories, Inc., Tokyo, Japan). The samples were applied directly onto $10 \%$ $(\mathrm{w} / \mathrm{v})$ polyacrylamide gels prepared in a 25 to $50 \%$ denaturing gradient using urea and formamide $(7 \mathrm{~mol} / \mathrm{L}$ urea and $40 \%$ (v/v) formamide as $100 \%$ denaturants).

Selected bands were excised from the DGGE gels, and the DNA was amplified by PCR by using the $357 \mathrm{f}$ (without GC-clamp) and $517 \mathrm{r}$ primers. After purifying the reaction products by using a commercial cleanup kit (GeneClean Kit, Qbiogene, Carlsbad, California, USA), the PCR products were cloned into the pTAC-1 vector, and the resulting 
plasmids were transformed into Escherichia coli DH5 $\alpha$ competent cells (DynaExpress TA Cloning Kit, BioDynamics Laboratory Inc., Tokyo, Japan). The sequencing reaction was performed using a BigDye Terminator v3.1 Cycle Sequencing kit (Applied Biosystems Inc., Foster City, California, USA), and the DNA sequences were analysed using an ABI PRISM 310 sequencer (Applied Biosystems Inc., Foster City, California, USA). BLAST searches of the GenBank database were performed to determine the closest relatives of partial 16S rRNA gene sequences.

\section{Data analysis}

The data were subjected to analysis of variance, and differences due to storage period were determined using Tukey's multiple comparison. Differences between the microbial populations in the silage at silo opening and the populations in the silage after aerobic stability test were determined using Student's $t$-test. These analyses were carried out using the JMP software (ver. 7; SAS Institute, Tokyo, Japan).

\section{RESULTS}

The DM contents were 212,170 , and $253 \mathrm{~g} / \mathrm{kg}$ and the WSC contents were $25,19.3$, and $70.4 \mathrm{~g} / \mathrm{kg}$ DM for fresh IR, GG, and WM crops, respectively (Table 1). The epiphytic LAB count at the time of ensiling was more than $10^{6} \mathrm{cfu} / \mathrm{g}$ in GG and WM, whereas the count was below the detectable level $\left(<10^{2} \mathrm{cfu} / \mathrm{g}\right)$ in IR.

Italian ryegrass silage fermentation characteristics and aerobic stability

2,3-Butanediol and ethanol were the predominant
Table 1. Characteristics of pre-ensiled crops

\begin{tabular}{lccc}
\hline Item & $\begin{array}{c}\text { Italian } \\
\text { ryegrass }\end{array}$ & $\begin{array}{c}\text { Guinea } \\
\text { grass }\end{array}$ & $\begin{array}{c}\text { Whole crop } \\
\text { maize }\end{array}$ \\
\hline $\begin{array}{l}\text { Dry matter (g/kg) } \\
\text { pH }\end{array}$ & 212 & 170 & 253 \\
Water soluble & 5.86 & 6.28 & 5.56 \\
$\quad$ carbohydrates (g/kg DM) & 124 & 18.4 & 70.4 \\
$\begin{array}{l}\text { Lactic acid bacteria } \\
\quad(\log \text { cfu/g) }\end{array}$ & $<2.00$ & 6.81 & 6.18 \\
$\quad$ Yeasts (log cfu/g) & 6.57 & 6.85 & 7.78 \\
Enterobacteria (log cfu/g) & 5.15 & 6.88 & 7.38 \\
\hline
\end{tabular}

Data are means of duplicate analyses.

fermentation products in the IR silage (Table 2). Alcoholic fermentation was intensive in the initial stages of ensiling; the amounts of 2,3-butanediol and ethanol on $\mathrm{d} 3$ were 58.2 and $27.7 \mathrm{~g} / \mathrm{kg} \mathrm{DM}$, respectively, and after further increases by about $10 \mathrm{~g} / \mathrm{kg}$ DM between $\mathrm{d} 3$ and 7 , the changes in the alcohol contents were small. The lactic acid content increased during the course of ensiling, from a low level on d 3 to a peak value on $\mathrm{d} 28$. The acetic acid content was low in the IR silage. Butyric acid production was seen from the beginning of fermentation, and on $\mathrm{d} 120$, the amount of butyric acid was more than that of lactic acid. The LAB numbers were counted at $10^{7} \mathrm{cfu} / \mathrm{g}$ levels, regardless of the ensiling period. Although yeasts were enumerated at $>10^{7}$ cfu/g until d 28, the counts were below the detectable levels after d 56. Likewise, enterobacteria levels were $>10^{7} \mathrm{cfu} / \mathrm{g}$ up to $\mathrm{d} 14$, after which they decreased to $10^{5} \mathrm{cfu} / \mathrm{g}$ on $\mathrm{d} 28$ and then became undetectable after $\mathrm{d} 56$.

When 14-d and 28-d silages were exposed to air, the lactic acid content decreased and the $\mathrm{pH}$ value increased, indicating significant deterioration. The counts of LAB, yeasts, and enterobacteria had increased to $10^{8}$ to $10^{9} \mathrm{cfu} / \mathrm{g}$

Table 2. Fermentation product contents and microbial counts of direct-cut Italian ryegrass silage determined at silo opening and after conducting a 7-d aerobic stability test

\begin{tabular}{|c|c|c|c|c|c|c|c|c|c|c|c|c|c|c|c|c|}
\hline \multirow[t]{2}{*}{ Item } & \multicolumn{6}{|c|}{ At silo opening } & \multirow[t]{2}{*}{$\mathrm{SE}$} & \multicolumn{4}{|c|}{ After 7 -d aerobic stability test } & \multirow[t]{2}{*}{ SE } & \multicolumn{4}{|c|}{$\begin{array}{c}t \text {-test for aerobic } \\
\text { spoilage }\end{array}$} \\
\hline & $3 \mathrm{~d}$ & $7 \mathrm{~d}$ & $14 \mathrm{~d}$ & $28 \mathrm{~d}$ & $56 \mathrm{~d}$ & $120 \mathrm{~d}$ & & $14 \mathrm{~d}$ & $28 \mathrm{~d}$ & $56 \mathrm{~d}$ & $120 \mathrm{~d}$ & & $14 \mathrm{~d}$ & $28 \mathrm{~d}$ & $56 \mathrm{~d}$ & $120 \mathrm{~d}$ \\
\hline$\overline{\mathrm{DM}}(\mathrm{g} / \mathrm{kg})$ & $186^{\mathrm{a}}$ & $182^{\mathrm{abc}}$ & $182^{\mathrm{abc}}$ & $183^{\mathrm{ab}}$ & $173^{\mathrm{c}}$ & $176^{\mathrm{bc}}$ & 1.98 & 189 & 178 & 175 & 189 & 7.89 & NS & NS & NS & NS \\
\hline $\mathrm{pH}$ & $5.54^{\mathrm{a}}$ & $5.47^{\mathrm{a}}$ & $5.04^{\mathrm{b}}$ & $4.97^{\mathrm{bc}}$ & $4.66^{\mathrm{d}}$ & $4.79^{\mathrm{cd}}$ & 0.05 & $6.72^{\mathrm{y}}$ & $7.05^{\mathrm{x}}$ & $4.73^{\mathrm{z}}$ & $4.81^{\mathrm{z}}$ & 0.17 & $* *$ & $* *$ & NS & NS \\
\hline $\mathrm{LA}(\mathrm{g} / \mathrm{kg} \mathrm{DM})$ & $8.66^{\mathrm{c}}$ & $21.4^{\mathrm{bc}}$ & $30.0^{\mathrm{ab}}$ & $40.0^{\mathrm{a}}$ & $39.6^{\mathrm{ab}}$ & $25.1^{\mathrm{abc}}$ & 3.91 & $8.91^{\mathrm{y}}$ & $6.68^{y}$ & $47.6^{\mathrm{x}}$ & $26.7^{x y}$ & 4.48 & $* *$ & $* *$ & NS & NS \\
\hline $\mathrm{C} 2(\mathrm{~g} / \mathrm{kg} \mathrm{DM})$ & $6.16^{\mathrm{b}}$ & $5.19^{\mathrm{b}}$ & $4.44^{\mathrm{b}}$ & $6.11^{\mathrm{b}}$ & $6.91^{\mathrm{ab}}$ & $13.7^{\mathrm{a}}$ & 1.46 & $8.85^{x y}$ & $6.22^{\mathrm{y}}$ & $11.7^{\mathrm{x}}$ & $13.8^{\mathrm{x}}$ & 3.57 & NS & NS & $*$ & NS \\
\hline C3 (g/kg DM) & $8.32^{\mathrm{a}}$ & $6.59^{\mathrm{ab}}$ & $4.91^{\mathrm{ab}}$ & $2.24^{\mathrm{b}}$ & $2.49^{\mathrm{b}}$ & $9.05^{\mathrm{a}}$ & 1.17 & $17.2^{x}$ & $4.03^{\mathrm{y}}$ & $11.8^{x y}$ & $6.05^{\mathrm{y}}$ & 4.45 & $* *$ & NS & $*$ & NS \\
\hline $2,3-\mathrm{BD}(\mathrm{g} / \mathrm{kg} \mathrm{DM})$ & $58.2^{\mathrm{b}}$ & $71.5^{\mathrm{ab}}$ & $67.0^{\mathrm{ab}}$ & $75.6^{\mathrm{ab}}$ & $64.3^{\mathrm{ab}}$ & $77.2^{\mathrm{a}}$ & 3.68 & $67.5^{x y}$ & $12.8^{\mathrm{y}}$ & $80.7^{x}$ & $68.3^{x y}$ & 5.78 & NS & $* *$ & NS & NS \\
\hline $\mathrm{C} 4(\mathrm{~g} / \mathrm{kg} \mathrm{DM})$ & $15.6^{\mathrm{b}}$ & $8.02^{\mathrm{b}}$ & $16.5^{\mathrm{b}}$ & $30.4^{\mathrm{a}}$ & $23.6^{\mathrm{ab}}$ & $36.7^{\mathrm{a}}$ & 1.21 & $12.0^{\mathrm{y}}$ & $5.69^{y}$ & $41.2^{\mathrm{x}}$ & $35.5^{\mathrm{x}}$ & 5.28 & NS & $* *$ & NS & NS \\
\hline $\begin{array}{l}\text { Ethanol } \\
\text { (g/kg DM) }\end{array}$ & $27.7^{\mathrm{b}}$ & $39.8^{\mathrm{a}}$ & $34.7^{\mathrm{ab}}$ & $39.3^{\mathrm{a}}$ & $33.7^{\mathrm{ab}}$ & $29.6^{\mathrm{b}}$ & 1.92 & $0.67^{y}$ & $0.77^{\mathrm{y}}$ & $8.54^{x}$ & $10.0^{\mathrm{x}}$ & 2.14 & $* *$ & $* *$ & $* *$ & $* *$ \\
\hline LAB $(\log \mathrm{cfu} / \mathrm{g})$ & 7.42 & 7.42 & 7.15 & 7.00 & 7.58 & 7.08 & 0.30 & $8.78^{\mathrm{x}}$ & $8.64^{x y}$ & $8.58^{x y}$ & $8.19^{y}$ & 0.12 & $* *$ & $* *$ & $*$ & $*$ \\
\hline Yeasts (log cfu/g) & 10.3 & 9.83 & 7.84 & 7.16 & $<2.00$ & $<2.00$ & 0.61 & $9.56^{\mathrm{x}}$ & $9.41^{\mathrm{x}}$ & $8.21^{x y}$ & $7.68^{y}$ & 0.37 & $* *$ & $* *$ & - & $* *$ \\
\hline ENB $(\log \mathrm{cfu} / \mathrm{g})$ & 8.74 & 8.87 & 7.10 & 4.90 & $<2.00$ & $<2.00$ & 0.17 & 9.30 & 9.00 & $<2.00$ & $<2.00$ & 0.12 & $* *$ & $* *$ & - & - \\
\hline
\end{tabular}

Silos were opened after 3, 7, 14, 28, 56, and $120 \mathrm{~d}$, and a 7-d aerobic stability test was conducted for the silages from the latter 4 silages.

Values with different letters ${ }^{\left({ }^{a-b}, x-y\right.}$ ) within a column are significantly different from one another. NS, $\mathrm{p} \geq 0.05 ; * \mathrm{p}<0.05 ; * * \mathrm{p}<0.01$.

$\mathrm{DM}=$ Dry matter; LA = Lactic acid; C2 = Acetic acid; C3 = Propionic acid; 2,3-BD = 2,3-butanediol; C4 = Butyric acid; LAB = Lactic acid bacteria;

$\mathrm{ENB}=$ Enterobacteria . 
Table 3. Fermentation product contents and microbial counts of direct-cut guinea grass silage determined at silo opening and after conducting a 7-d aerobic stability test

\begin{tabular}{|c|c|c|c|c|c|c|c|c|c|c|c|c|c|c|c|c|}
\hline \multirow[t]{2}{*}{ Item } & \multicolumn{6}{|c|}{ At silo opening } & \multirow[t]{2}{*}{ SE } & \multicolumn{4}{|c|}{ After 7-d aerobic stability test } & \multirow[t]{2}{*}{ SE } & \multicolumn{4}{|c|}{$\begin{array}{c}\text { t-test for aerobic } \\
\text { spoilage }\end{array}$} \\
\hline & $3 \mathrm{~d}$ & $7 \mathrm{~d}$ & $14 \mathrm{~d}$ & $28 \mathrm{~d}$ & $56 \mathrm{~d}$ & $120 \mathrm{~d}$ & & $14 \mathrm{~d}$ & $28 \mathrm{~d}$ & $56 \mathrm{~d}$ & $120 \mathrm{~d}$ & & $14 \mathrm{~d}$ & $28 \mathrm{~d}$ & $56 \mathrm{~d}$ & $120 \mathrm{~d}$ \\
\hline $\mathrm{DM}(\mathrm{g} / \mathrm{kg})$ & $166^{\mathrm{a}}$ & $162^{\mathrm{ab}}$ & $167^{\mathrm{a}}$ & $152^{\mathrm{b}}$ & $153^{\mathrm{b}}$ & $151^{\mathrm{b}}$ & 2.40 & $166^{x}$ & $162^{x y}$ & $163^{x}$ & $151^{\mathrm{y}}$ & 2.66 & NS & * & * & NS \\
\hline $\mathrm{pH}$ & $5.96^{\mathrm{bc}}$ & $6.01^{\mathrm{bc}}$ & $5.58^{\mathrm{d}}$ & $6.67^{\mathrm{a}}$ & $6.19^{\mathrm{b}}$ & $5.80^{\mathrm{cd}}$ & 0.06 & $8.96^{\mathrm{x}}$ & $8.72^{\mathrm{x}}$ & $6.01^{y}$ & $5.71^{z}$ & 0.06 & $* *$ & $* *$ & NS & NS \\
\hline LA (g/kg DM) & $14.0^{\mathrm{a}}$ & $7.67^{\mathrm{bc}}$ & $11.2^{\mathrm{ab}}$ & $2.96^{\mathrm{cd}}$ & $1.34^{\mathrm{d}}$ & $2.96^{\mathrm{cd}}$ & 1.15 & 0.00 & 0.42 & 0.32 & 1.53 & 0.49 & $* *$ & $* *$ & NS & NS \\
\hline $\mathrm{C} 2(\mathrm{~g} / \mathrm{kg} \mathrm{DM})$ & $26.0^{c}$ & $39.6^{\mathrm{b}}$ & $42.1^{\mathrm{b}}$ & $44.9^{\mathrm{b}}$ & $56.8^{\mathrm{a}}$ & $57.8^{\mathrm{a}}$ & 2.15 & $0.00^{\mathrm{y}}$ & $2.13^{\mathrm{y}}$ & $50.0^{\mathrm{x}}$ & $54.5^{\mathrm{x}}$ & 5.77 & $* *$ & $* *$ & NS & NS \\
\hline $\mathrm{C} 3(\mathrm{~g} / \mathrm{kg} \mathrm{DM})$ & $0.60^{\mathrm{a}}$ & $0.00^{\mathrm{a}}$ & $1.00^{\mathrm{a}}$ & $2.26^{\mathrm{a}}$ & $3.25^{\mathrm{a}}$ & $2.32^{\mathrm{a}}$ & 0.90 & 0.00 & 0.00 & 0.86 & 1.63 & 0.60 & NS & NS & NS & NS \\
\hline 2,3-BD (g/kg DM) & 4.47 & 4.35 & 4.28 & 3.91 & 2.34 & 6.21 & 0.95 & $0.00^{\mathrm{y}}$ & $0.00^{\mathrm{y}}$ & $8.66^{\mathrm{x}}$ & $8.68^{x}$ & 7.29 & $* *$ & $*$ & $*$ & $*$ \\
\hline $\mathrm{C} 4(\mathrm{~g} / \mathrm{kg} \mathrm{DM})$ & $0.00^{\mathrm{b}}$ & $0.00^{\mathrm{b}}$ & $0.00^{\mathrm{b}}$ & $8.66^{\mathrm{a}}$ & $14.7^{\mathrm{a}}$ & $62.4^{\mathrm{c}}$ & 19.4 & $0.00^{y}$ & $0.00^{\mathrm{y}}$ & $11.5^{\mathrm{x}}$ & $36.3^{x}$ & 3.28 & NS & NS & NS & $* *$ \\
\hline $\begin{array}{l}\text { Ethanol } \\
\text { (g/kg DM) }\end{array}$ & $3.20^{\mathrm{b}}$ & $7.09^{\mathrm{ab}}$ & $7.48^{\mathrm{ab}}$ & $10.3^{\mathrm{ab}}$ & $18.9^{\mathrm{a}}$ & $18.9^{\mathrm{a}}$ & 2.73 & $0.00^{\mathrm{y}}$ & $0.00^{\mathrm{y}}$ & $7.50^{x}$ & $5.90^{x}$ & 1.73 & $*$ & $*$ & * & $*$ \\
\hline LAB $(\log \mathrm{cfu} / \mathrm{g})$ & 8.97 & 8.66 & 8.31 & 8.00 & 8.02 & 8.07 & 0.30 & $6.04^{\mathrm{y}}$ & $7.95^{\mathrm{x}}$ & $8.13^{\mathrm{x}}$ & $7.68^{x}$ & 0.15 & $*$ & NS & NS & * \\
\hline Yeasts (log cfu/g) & $7.85^{\mathrm{ab}}$ & $7.32^{\mathrm{b}}$ & $7.14^{\mathrm{b}}$ & $8.22^{\mathrm{a}}$ & $8.12^{\mathrm{a}}$ & $8.15^{\mathrm{a}}$ & 0.26 & $7.21^{\mathrm{y}}$ & $8.86^{\mathrm{x}}$ & $8.83^{\mathrm{x}}$ & $7.66^{y}$ & 0.33 & NS & NS & * & * \\
\hline ENB (log cfu/g) & 7.01 & 6.84 & 6.76 & 7.52 & 7.10 & 6.83 & 0.21 & $7.06^{\mathrm{xy}}$ & $9.02^{x}$ & $7.77^{\mathrm{xy}}$ & $5.38^{\mathrm{y}}$ & 0.60 & NS & ** & NS & * \\
\hline
\end{tabular}

Silos were opened after $3,7,14,28,56$, and $120 \mathrm{~d}$, and a 7-d aerobic stability test was conducted for the silages from the latter 4 silages.

Values with different letters $\left({ }^{a-b, x-y}\right)$ within a column are significantly different from one another. NS, $\mathrm{p} \geq 0.05 ; * \mathrm{p}<0.05 ; * * \mathrm{p}<0.01$.

$\mathrm{DM}=$ Dry matter; $\mathrm{LA}=$ Lactic acid; $\mathrm{C} 2=$ Acetic acid; $\mathrm{C} 3=$ Propionic acid; 2,3-BD = 2,3-butanediol; $\mathrm{C} 4=$ Butyric acid; LAB = Lactic acid bacteria; $\mathrm{ENB}=$ Enterobacteria.

from $10^{7} \mathrm{cfu} / \mathrm{g}$ at silo opening. When $56-\mathrm{d}$ and $120-\mathrm{d}$ silages were subjected to aerobic stability tests, only a few changes were seen in the fermentation products, and thus, despite the increase in the yeast counts from undetectable levels at silo opening to $10^{7}$ to $10^{8} \mathrm{cfu} / \mathrm{g}$ levels, these silages were considered unspoiled. Small increases in the acetic acid and propionic acid contents were detected in the 56-d silage during the 7-d spoilage test.

\section{Guinea grass silage fermentation characteristics and aerobic stability}

Acetic acid was the predominant product in the GG silage (Table 3); the content was $26.0 \mathrm{~g} / \mathrm{kg} \mathrm{DM}$ on d 3 and then increased to $57.8 \mathrm{~g} / \mathrm{kg}$ DM on d 120. Lactic acid, which was second to acetic acid in the initial stages of ensiling, decreased greatly after d 14 , and only $3.0 \mathrm{~g} / \mathrm{kg} \mathrm{DM}$ was recorded on $d$ 120. Distinctive changes were not observed in the 2,3-butanediol content over the course of ensiling. On the other hand, with prolonged ensiling, the ethanol content increased. With prolonged ensiling, butyric acid content also increased, and although it was not detected until d 14, the production was substantially enhanced from $\mathrm{d} 28$, and finally, a level of $62.4 \mathrm{~g} / \mathrm{kg}$ DM was observed on d 120. Large numbers of LAB, yeasts, and enterobacteria were detected at silo opening, regardless of the ensiling period.

After exposing the 14-d and 28-d GG silages to air, aerobic deterioration occurred, and the lactic acid, acetic acid, 2,3-butanediol, and ethanol contents decreased. Upon aerobic spoilage, the numbers of $\mathrm{LAB}$ and yeasts decreased, whereas that of enterobacteria increased. Aerobic deterioration did not take place in the 56- and 120-d silages. Although the counts of yeasts had increased in the 56-d silage after the 7-d spoilage test, those of LAB, yeasts, and enterobacteria decreased in the 120 -d silage.

\section{Whole-crop maize silage fermentation characteristics and aerobic stability}

Lactic acid production was intensive from the beginning of fermentation in WM silage (Table 4). The content on d 3 was $50.4 \mathrm{~g} / \mathrm{kg} \mathrm{DM}$, and the peak value was shown on $\mathrm{d} 28$. Although the acetic acid content was kept below one-third of the lactic acid content, it increased greatly after d 56 and reached the maximum on $\mathrm{d} 120$. The ethanol content was stable from the beginning to the end of fermentation. The LAB count was the highest on d 3 and then decreased gradually to $10^{6} \mathrm{cfu} / \mathrm{g}$ levels on d 120 . Similarly, yeast numbers decreased during prolonged ensiling. Although enterobacteria were counted at $10^{7} \mathrm{cfu} / \mathrm{g}$ levels in preensiled crops, the counts were below the detectable levels throughout the ensiling period.

When the 14-, 28-, and 56-d WM silages were exposed to air, the lactic acid, acetic acid, and ethanol contents showed a decrease, whereas the $\mathrm{pH}$ values showed increases. Upon aerobic spoilage, the LAB and yeasts counts increased from $10^{7}$ to $10^{8} \mathrm{cfu} / \mathrm{g}$ to $10^{9} \mathrm{cfu} / \mathrm{g}$ levels, and that of enterobacteria was determined to $10^{4} \mathrm{cfu} / \mathrm{g}$, although the levels at silo opening were $<10^{2} \mathrm{cfu} / \mathrm{g}$.

\section{Italian ryegrass silage bacterial community}

The DGGE patterns were different between the time of ensiling and d 3 in the IR silage (Figure 1). Distinctive bands of Pantoea agglomerans (band 5), Enterobacter sp. (bands 6 and 9), Enterococcus faecium (band 7), and Rahnella aquatilis (band 8) were detected over the course of ensiling. A band indicative of Clostridium butyricum 
Table 4. Fermentation product contents and microbial counts of whole-crop maize silage determined at silo opening and after conducting a 7-d aerobic stability test

\begin{tabular}{|c|c|c|c|c|c|c|c|c|c|c|c|c|c|c|c|c|}
\hline \multirow{2}{*}{ Item } & \multicolumn{6}{|c|}{ At silo opening } & \multirow{2}{*}{ SE } & \multicolumn{4}{|c|}{ After 7-d aerobic stability test } & \multirow{2}{*}{ SE } & \multicolumn{4}{|c|}{ t-test for aerobic spoilage } \\
\hline & $3 d$ & $7 \mathrm{~d}$ & $14 \mathrm{~d}$ & $28 d$ & $56 \mathrm{~d}$ & $\overline{120 \mathrm{~d}}$ & & $14 \mathrm{~d}$ & $28 \mathrm{~d}$ & $56 \mathrm{~d}$ & $120 \mathrm{~d}$ & & $14 \mathrm{~d}$ & $28 \mathrm{~d}$ & $56 \mathrm{~d}$ & $120 \mathrm{~d}$ \\
\hline$\overline{\mathrm{DM}}(\mathrm{g} / \mathrm{kg})$ & $234^{\mathrm{b}}$ & $248^{\mathrm{ab}}$ & $266^{\mathrm{a}}$ & $239^{\mathrm{b}}$ & $231^{\mathrm{b}}$ & $237^{\mathrm{b}}$ & 5.68 & $255^{\mathrm{x}}$ & $241^{x}$ & $252^{x}$ & $256^{\mathrm{y}}$ & 9.90 & NS & NS & NS & NS \\
\hline $\mathrm{pH}$ & $3.85^{\mathrm{b}}$ & $3.79^{\mathrm{bc}}$ & $3.73^{\mathrm{cd}}$ & $4.00^{\mathrm{a}}$ & $3.73^{\text {cd }}$ & $3.65^{\mathrm{d}}$ & 0.02 & $6.46^{\mathrm{x}}$ & $6.24^{x}$ & $6.21^{\mathrm{x}}$ & $3.59^{\mathrm{y}}$ & 0.07 & $* *$ & $* *$ & $* *$ & NS \\
\hline $\mathrm{LA}(\mathrm{g} / \mathrm{kg} \mathrm{DM})$ & $50.4^{\mathrm{b}}$ & $64.2^{\mathrm{ab}}$ & $58.6^{\mathrm{ab}}$ & $72.5^{\mathrm{a}}$ & $65.9^{\mathrm{a}}$ & $69.9^{\mathrm{a}}$ & 3.26 & $7.53^{\mathrm{y}}$ & $3.38^{\mathrm{y}}$ & $6.72^{y}$ & $74.6^{\mathrm{x}}$ & 2.23 & $* *$ & $*$ & $* *$ & NS \\
\hline $\mathrm{C} 2(\mathrm{~g} / \mathrm{kg} \mathrm{DM})$ & $15.0^{\mathrm{b}}$ & $16.9^{\mathrm{ab}}$ & $14.0^{\mathrm{b}}$ & $18.3^{\mathrm{ab}}$ & $19.0^{\mathrm{ab}}$ & $29.9^{\mathrm{a}}$ & 1.06 & $5.28^{\mathrm{y}}$ & $5.90^{\mathrm{y}}$ & $5.89^{\mathrm{y}}$ & $22.7^{x}$ & 0.73 & $* *$ & $*$ & $* *$ & NS \\
\hline C3 (g/kg DM) & - & - & - & - & - & - & - & - & - & - & - & - & - & - & - & - \\
\hline 2,3-BD (g/kg DM) & - & - & - & - & - & - & - & - & - & - & - & - & - & - & - & - \\
\hline $\mathrm{C} 4(\mathrm{~g} / \mathrm{kg} \mathrm{DM})$ & - & - & - & - & - & - & - & - & - & - & - & - & - & - & - & - \\
\hline $\begin{array}{l}\text { Ethanol } \\
(\mathrm{g} / \mathrm{kgDM})\end{array}$ & 16.7 & 19.7 & 15.2 & 16.8 & 20.6 & 17.9 & 2.05 & $0.00^{\mathrm{y}}$ & $0.00^{\mathrm{y}}$ & $0.00^{\mathrm{y}}$ & $15.48^{x}$ & 0.27 & $*$ & $*$ & $* *$ & NS \\
\hline $\mathrm{LAB}(\log \mathrm{cfu} / \mathrm{g})$ & $8.92^{\mathrm{a}}$ & $8.76^{\mathrm{a}}$ & $8.28^{\mathrm{b}}$ & $8.13^{b}$ & $7.87^{\mathrm{b}}$ & $6.23^{\mathrm{c}}$ & 0.10 & $9.19^{x}$ & $8.98^{\mathrm{x}}$ & $9.64^{x}$ & $6.88^{\mathrm{y}}$ & 0.15 & $*$ & $*$ & $* *$ & NS \\
\hline Yeasts (log cfu/g) & $6.62^{\mathrm{c}}$ & $5.82^{\mathrm{d}}$ & $8.25^{\mathrm{a}}$ & $8.24^{\mathrm{a}}$ & $7.50^{\mathrm{b}}$ & $6.23^{\mathrm{cd}}$ & 0.15 & $9.63^{x}$ & $9.77^{x}$ & $9.82^{x}$ & $4.64^{y}$ & 0.15 & $*$ & $*$ & $* *$ & $*$ \\
\hline ENB $(\log \mathrm{cfu} / \mathrm{g})$ & $<2.00$ & $<2.00$ & $<2.00$ & $<2.00$ & $<2.00$ & $<2.00$ & - & 4.94 & 4.41 & 4.61 & $<2.00$ & - & - & - & - & - \\
\hline
\end{tabular}

Silos were opened after 3, 7, 14, 28,56, and $120 \mathrm{~d}$, and a 7-day aerobic stability test was conducted for the silages from the latter 4 silages.

Values with different letters $\left({ }^{a-b}, x-y\right)$ within a column are significantly different from one another. NS, $\mathrm{p} \geq 0.05 ; * \mathrm{p}<0.05 ; * * \mathrm{p}<0.01$.

$\mathrm{DM}=$ Dry matter; LA = Lactic acid; C2 = Acetic acid; C3 = Propionic acid; 2,3-BD = 2,3-butanediol; C4 = Butyric acid; LAB = Lactic acid bacteria; $\mathrm{ENB}=$ Enterobacteria.

(band 10) was detected on $\mathrm{d} 7$ and was detected up to the end of ensiling. When 14- and 28-d silages were examined after the 7-d aerobic stability test, several non-LAB species such as Staphylococcus sciuri (bands 12 and 13), Bacillus subtilis (band 15), and Acinetobacter sp. (band 17) were newly detected. Although distinctive spoilage was not seen, the DGGE patterns of 56- and 120-d silages appeared to be similar to those of aerobically spoiled $14-$ and 28 -d silages, respectively.

\section{Guinea grass silage bacterial community}

The DGGE patterns of the GG silage were also different from that of pre-ensiled crop from the beginning of fermentation (Figure 2). Many LAB species such as $L$. plantarum (band 22), L. brevis (band 24), L. lactis (bands 28 and 29), and Lactococcus garvieae (band 31) were detected in addition to non-LAB species such as Klebsiella sp. (band 21) and Morganella morganii (band 26). When the ensiling was prolonged, a number of new bands indicative of $L$. plantarum (band 25) and Enterobacter cloacae (band 32) were detectable. In spoiled 14- and 28-d silages, the number of DGGE bands increased during the 7-d spoilage test. In stable GG silages, however, the DGGE patterns appeared unchanged between before and after

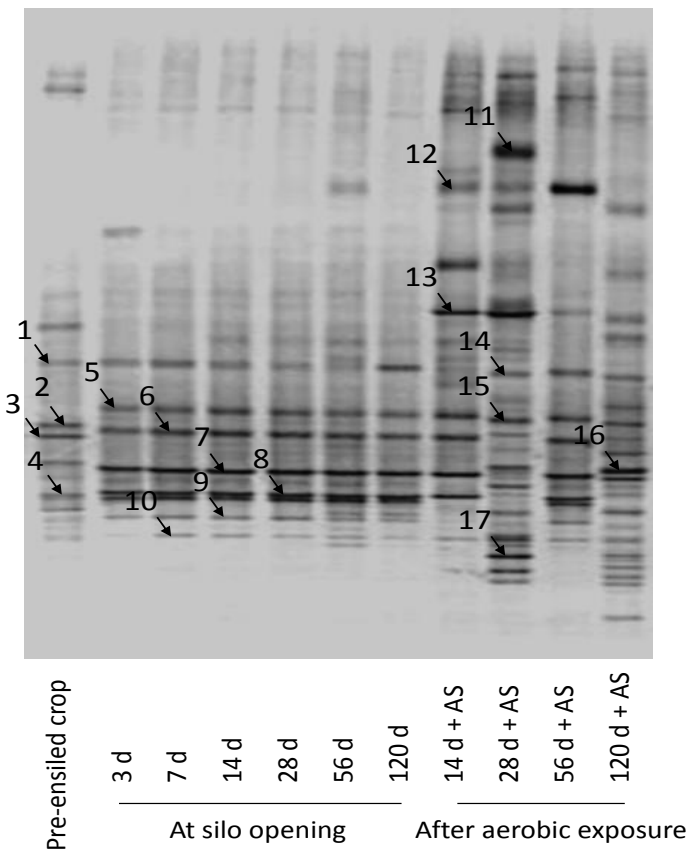

1 Uncultured bacterium

2 Sphingomonas sp.

3 Uncultured bacterium

4 Enterobacter sp.

5 Pantoea agglomerans

6 Enterobactersp.

7 Enterococcus faecium

8 Rahnella aquatilis

9 Enterobactersp.

10 Clostridium butyricum

11 Uncultured bacterium

12 Staphylococcus sciuri

13 Staphylococcus sciuri

14 Enterobactersp.

15 Bacillus subtilis

16 Enterobactersp.

17 Acinetobactersp.

Figure 1. Bacterial communities in the ensiling process of direct-cut Italian ryegrass silage. Silos were opened after 3, 7, 14, 28, 56, and $120 \mathrm{~d}$ and a 7-d aerobic stability test was conducted for the silages from the latter 4 silages. 


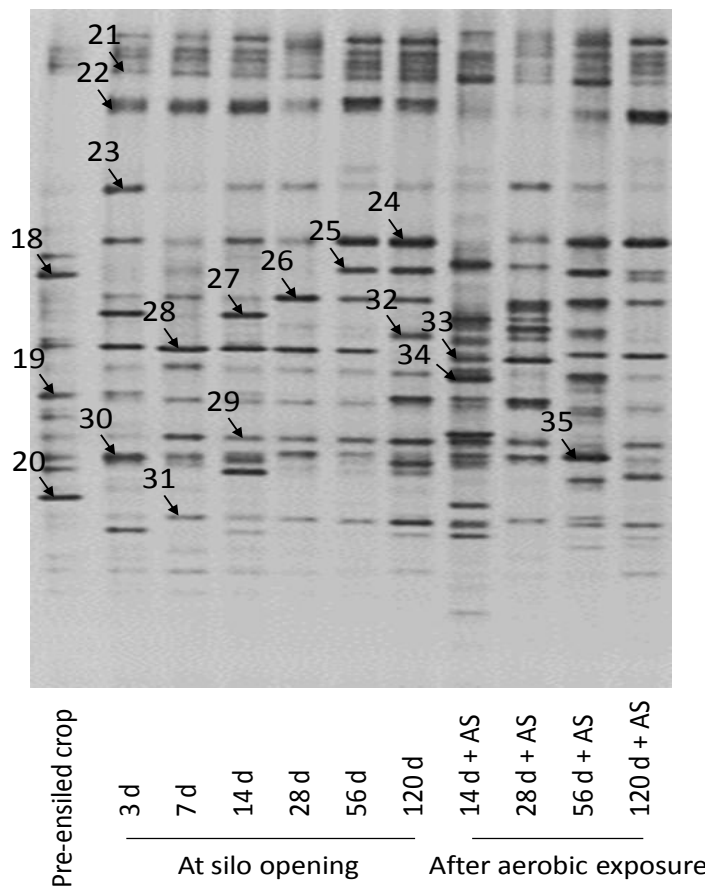

18 Acinetobacter sp

19 Klebsiella sp.

20 Acinetobacter sp.

21 Klebsiella sp.

22 Lactobacillus plantarum

23 Enterococcus sulfureus

24 Lactobacillus brevis

25 Lactobacillus plantarum

26 Morganella morganii

27 Uncultured bacterium

28 Lactococcus lactis

29 Lactococcus lactis

30 Pantoea agglomerans

31 Lactococcus garviae

32 Enterobacter cloacae

33 Enterobacter cloacae

34 Pantoea ananatis

35 Pantoea agglomerans

Figure 2. Bacterial communities in the ensiling process of direct-cut guinea grass silage. Silos were opened after 3, 7, 14, 28, 56, and 120 $\mathrm{d}$ and a 7-d aerobic stability test was conducted for the silages from the latter 4 silages.

exposure to air.

\section{Whole-crop maize silage bacterial community}

Marked changes in the DGGE patterns were observed during the initial 3-d ensiling in the WM silage (Figure 3). Nearly all the bands detectable on d 3 were LAB; Weissella paramesenteroides (band 38), L. plantarum (bands 39 and 42), L. lactis (band 40), L. brevis (band 41), Pediococcus pentosaceus (band 47), Pediococcus parvulus (band 43), and Weissella confusa (band 45) were detected. Except the aerobically stable 120 -d silage, the bands for L. plantarum and $P$. parvulus disappeared, whereas those for B. subtilis

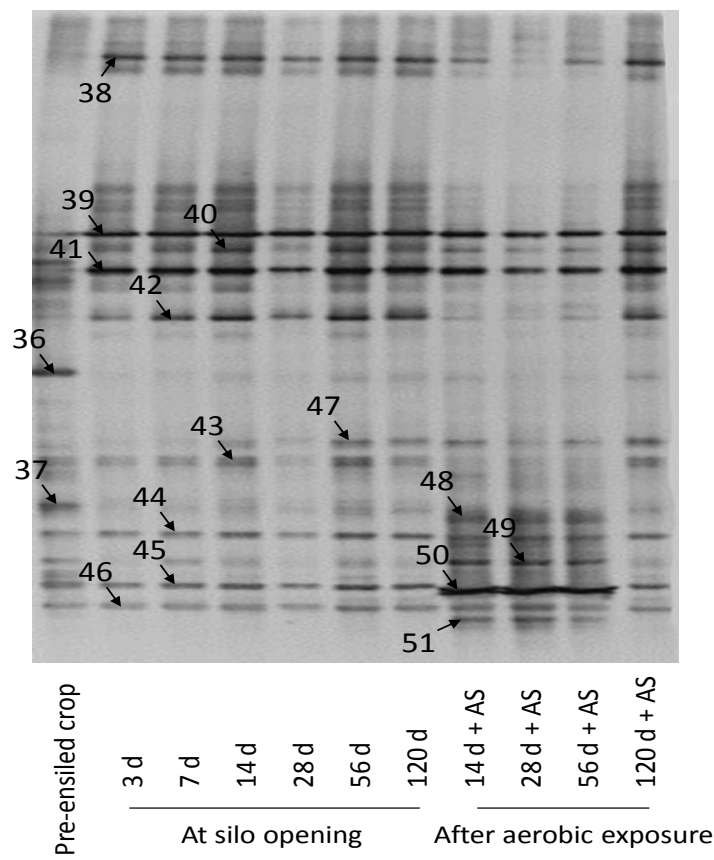

36 Uncultured bacterium

37 Uncultured bacterium

38 Weissella paramesenteroides

39 Lactobacillus plantarum

40 Lactococcus lactis

41 Lactobacillus brevis

42 Lactobacillus plantarum

43 Pediococcus parvulus

44 Lactobacillus brevis

45 Weissella confusa

46 Klebsiella pneumoniae

47 Pediococcus pentosaceus

48 Bacillus subtilis

49 Enterobacter cloacae

50 Acetobacter pasteurianus

51 Acetobacter pasteurianus

Figure 3. Bacterial communities in the ensiling process of whole-crop maize silage. Silos were opened after 3, 7, 14, 28, 56, and 120 d and a $7-d$ aerobic stability test was conducted for the silages from the latter 4 silages. 
(band 48), E. cloacae (band 49), and Acetobacter pasteurianus (bands 50 and 51) newly appeared after the 7$\mathrm{d}$ aerobic stability test.

\section{DISCUSSION}

Although sufficient levels of the WSC content were found in the pre-ensiled crops, 2,3-butanediol and ethanol production were enhanced in the IR silage, whereas intensive lactic acid production was seen in the WM silage. The bacterial community data were consistent with these differences; many types of enterobacteria were detected from the beginning of fermentation in the IR silage, whereas nearly all DGGE bands on $\mathrm{d} 3$ were identified as $\mathrm{LAB}$ in the WM silage. Because epiphytic LAB numbers were $<10^{2} \mathrm{cfu} / \mathrm{g}$ in pre-ensiled IR, the enterobacteria detected on d 3 may have outcompeted the other bacteria and produced large amounts of 2,3-butanediol and ethanol. Notably, the enterobacteria found in the pre-ensiled IR were promptly replaced by enterobacteria that had adapted to the silage environment. This implies that, although increases in the enterobacterial count were small during the initial 3-d ensiling, the community structure was greatly altered. However, few differences were seen in the DGGE patterns of the IR silage after $d 56$, although the enterobacterial counts were below the detectable levels on d 56 and 120 . Moreover, the changes observed in the DGGE patterns could not explain how the lactic acid content gradually increased until d 28 in the IR silage. DGGE analysis is qualitative or semi-quantitative, and thus limitations exist in understanding the changes in the metabolic activities of microorganisms. Nevertheless, the analysis was helpful in detecting the association of $C$. butyricum in the IR silage; the DNA band was visible from the beginning of fermentation, accounting for the production of butyric acid from the initial stages of ensiling.

In tropical ensiling, acetic acid rather than lactic acid often becomes the predominant fermentation product (Catchpoole and Henzell, 1971; Parvin and Nishino, 2009). High-moisture preparation and prolonged ensiling may intensify this acetic acid fermentation (Nishino et al., 2012); hence, the use of direct-cut GG and assessments from the initial to the late stages of fermentation could help in understanding which types of bacteria are involved in the tropical grass silage. However, the bacteria associated with the enhanced acetic acid production from the beginning of fermentation were not clearly identified. Although the appearance of L. plantarum (band 25) and M. morganii (band 26) after d 28 could account for the increase in the acetic acid content in the late stages of ensiling, no distinctive changes were seen in the DGGE patterns between $\mathrm{d} 3$ and 7, during which marked changes in the lactic and acetic acid contents occurred. We have speculated that L. plantarum is involved in the increase in acetic acid content as a result of prolonged ensiling (Parvin and Nishino, 2009; Nishino et al., 2012), because L. plantarum can metabolize lactic acid to acetic acid under sugardeficient conditions (Lindgren et al., 1990). The same metabolic process may have occurred in this study because L. plantarum (band 22) was detected from the initial stage to the end of GG ensiling. Nevertheless, the increase in the acetic acid content was much greater than the decrease in the lactic acid content; hence, lactic acid metabolism could account for a part of the enhancement of acetic acid fermentation. In this regard, the amino acid-degrading activities of $M$. morganii and other bacteria might have contributed to the increase in the acetic acid content. However, although a distinctive increase in the butyric acid content was observed after d 56, no bands indicative of Clostridium spp. were seen in the bacterial community of the GG silage.

In the case of WM ensiling, the fermentation products data were consistent with the bacterial community data and accounted for the enhanced lactic acid production from the beginning of fermentation. This is because almost all DGGE bands were detected as LAB species and few changes were seen from the prolonged ensiling in both the amount of the fermentation products and the DGGE band patterns. Small increases in the lactic acid and acetic acid contents during long storage periods may indicate sustained activities of hetero-fermentative LAB species.

In this study, the results of DGGE analysis helped to account for the differences in the composition of the fermentation products among the IR, GG, and WM silages; however, these results could not explain how acetic acid fermentation is enhanced in the GG silage. The changes in the bacterial community that had taken place in the first $3 \mathrm{~d}$ of ensiling could be considered interesting findings. Regardless of the silage crops, the DGGE patterns on d 3 were different from that on the day of ensiling. Although $>10^{6} \mathrm{cfu} / \mathrm{g}$ levels of LAB were counted in the GG and the $\mathrm{WM}$ at the time of ensiling, the composition of LAB species was greatly altered during the first $3 \mathrm{~d}$ of ensiling. Given that DGGE analysis is not quantitative, small populations may be difficult to detect. Therefore, the prompt changes in the DGGE patterns found at the very beginning of fermentation suggest that, although a large number of LAB were enumerated in the pre-ensiled crop, many of these may be outcompeted by the LAB species that are adaptable to the silage environment.

Differences were also seen between the silage crops in the bacterial species that appeared upon aerobic spoilage. Enterobacter sp. was detected in common among all 3 spoiled crop silages, Bacillus sp. was present in the spoiled IR and WM silages, S. sciuri was observed in the spoiled IR silage, and A. pasteurianus was detected in the spoiled WM 
silage. Because we examined the bacterial community before and after the 7-d aerobic stability test, we could not ascertain whether these bacteria were spoilage-initiating or follow-up species. Yeasts, moulds, and acetic acid bacteria are considered the main microorganisms associated with aerobic spoilage; however, the populations of Bacillus spp. and enterobacteria may also increase when the silage is spoiled (Woolford 1990; Driehuis and Oude Elferink, 2000). A. pasteurianus is known to show strong crop specificity with respect to the corn and cereal silages it inhabits (Oude Elferink et al., 2001), which was reasonably confirmed in this study.

Aerobic spoilage did not take place in the IR and GG silages unloaded on d 56 and 120, and in the WM silage unloaded on $\mathrm{d} 120$. The main fermentation products that inhibit yeasts and moulds are acetic, propionic, and butyric acids in the silage; hence, the increased acetic and butyric acids in the IR and GG silages and the increased acetic acid in the WM silage could function as inhibitory substances. Because the GG silage showed high acetic acid content (>26.0 g/kg DM) from d 3, explaining why the 14- and 28-d silages were spoiled would be difficult. However, the GG silages had high $\mathrm{pH}$ values (>6.0); hence, the proportion of undissociated acetic acid was calculated to be approximately 0.10 . In contrast, the 120-d WM silage showed a low $\mathrm{pH}$ of 3.65 , and therefore, $>0.90$ of the acetic acid was present in the undissociated form. For the suppression of microorganisms, undissociated acid is of primary importance, and dissociated molecules have minor effects (Courtin and Spoelstra, 1990; Muck et al., 1991). Therefore, the results in this study reconfirm the importance of undissociated acids in spoilage inhibition.

\section{CONCLUSIONS}

Changes in the live counts, fermentation product contents, and composition of the bacterial communities were examined from d 3 to d 120 in the course of ensiling of the IR, GG, and WM silages. DGGE analysis reasonably accounted for the types of bacteria that dictated alcoholic fermentation in the IR silage and lactic acid fermentation in the WM silage. Although the analysis did not help in identifying the bacterial species responsible for acetic acid fermentation in the GG silage, metabolic changes rather than changes in the community structure were suggested to be involved in the fermentation. When marked changes were detected in the amount of the fermentation products, distinctive changes were also found in the bacterial community structures. However, we could not ascertain whether these were spoilage-initiating or follow-up bacteria. Although our results demonstrate the usefulness of DGGE analysis in elucidating the ensiling process, data from plate cultures are also helpful for adding quantitative information to the data from DGGE analysis.

\section{ACKNOWLEDGEMENTS}

The work was supported by Scientific Research Foundation for the Returned Overseas Chinese Scholars, State Educational Commission of Heilongjiang Province of China (No. 1252HQ009).

\section{REFERENCES}

Ampe, F., O. N. Ben, C. Moizan, C. Wacher, and J. P. Guyot. 1999. Polyphasic study of the spatial distribution of microorganisms in Mexican pozol, a fermented maize dough, demonstrates the need for cultivation-independent methods to investigate traditional fermentations. Appl. Environ. Microbiol. 65:54645473.

Catchpoole, V. R., and E. F. Henzell. 1971. Silage and silagemaking from tropical herbage species. Herbage Abstr. 41:213-221.

Courtin, M. G., and S. F. Spoelstra. 1990. A simulation model of the microbiological and chemical changes accompanying the initial stage of aerobic deterioration of silage. Grass Forage Sci. 45:153-165.

Driehuis, F., and E. S. Oude. 2000. The impact of the quality of silage on animal health and food safety: A review. Vet. Q. 22:212-216.

Giraffa, G., and E. Neviani. 2001. DNA-based, cultureindependent strategies for evaluating microbial communities in food-associated ecosystems. Int. J. Food Microbiol. 67:19-34.

Li, Y., and N. Nishino. 2011a. Bacterial and fungal communities of wilted Italian ryegrass silage inoculated with and without Lactobacillus rhamnosus or Lactobacillus buchneri. Lett. Appl. Microbiol. 52:314-321.

Li, Y., and N. Nishino. 2011b. Effects of inoculation of Lactobacillus rhamnosus and Lactobacillus buchneri on fermentation, aerobic stability and microbial communities in whole crop corn silage. Grassl. Sci. 57:184-191.

Li, Y., and N. Nishino. 2011c. Monitoring the bacterial community of maize silage stored in a bunker silo inoculated with Enterococcus faecium, Lactobacillus plantarum and Lactobacillus buchneri. J. Appl. Microbiol. 110:1561-1570.

Lin, C., K. K. Bolsen, B. E. Brent, and D. Y. Fung. 1992. Epiphytic lactic acid bacteria succession during the preensiling and ensiling periods of alfalfa and maize. J. Appl. Bacteriol. 73:375-387.

Lindgren, S. E., L. T. Axelsson, and R. F. McFeeters. 1990. Anaerobic L-lactate degradation by Lactobacillus plantarum. FEMS Microbiol. Lett. 66:209-213.

McDonald, P., A. R. Henderson, and S. J. Heron. 1991. The biochemistry of silage. Chalcombe Publications, Lincoln, UK.

Muck, R. E., R. E. Pitt, and R. Y. Leibensperger. 1991. A model of aerobic fungal growth in silage: 1. Microbial characteristics. Grass Forage Sci. 46:283-299.

Nishino, N., Y. Li, C. Wang, and S. Parvin. 2012. Effects of wilting and molasses addition on fermentation and bacterial community in guinea grass silage. Lett. Appl. Microbiol. $54: 175-181$. 
Nussio, L. G. 2005. Silage production from tropical forages. In: Silage production and utilization (Ed. R. S. Park, and M. D. Stronge), Wageningen Academic Publishers, Wageningen. pp 97-107.

Oude, E. S., F. Driehuis, P. M. Becker, J. C. Gottschal, F. Faber, and S. F. Spoelstra. 2001. The presence of Acetobacter sp. in ensiled forage crops and ensiled industrial byproducts. Med. Fac. Landbouww. Univ. Gent. 66:427-430.
Parvin, S., and N. Nishino. 2009. Bacterial community associated with ensilage process of wilted guinea grass. J. Appl. Microbiol. 107:2029-2036.

Parvin, S., and N. Nishino. 2010. Succession of lactic acid bacteria in wilted rhodesgrass silage assessed by plate culture and denaturing gradient gel electrophoresis. Grassl. Sci. 56:51-55.

Woolford, M. K. 1990. The detrimental effects of air on silage. J. Appl. Bacteriol. 68:101-116. 